\title{
Russell body cervicitis: a case report
}

\author{
Abd Al-Rahman Mohammad Foda ${ }^{1}$, Asem Ali Shalaby ${ }^{1,2}$, Amira Kamal El-Hawary ${ }^{1}$ \\ 1. Pathology department, faculty of medicine, Mansoura University, Egypt. 2. Pathology department, College of medicine \\ and health sciences, Sultan Qaboos University, Oman.
}

Correspondence: Asem Ali Shalaby. Address: Pathology department, College of Medicine and Health Sciences, Sultan Qaboos University, Postal Code: 123, Al-Khod, Muscat, Sultanate of Oman. E-mail: asemali444@yahoo.com

Received: January 12, 2014

Accepted: May 5, 2014

Online Published: May 19, 2014

DOI : $10.5430 /$ crcp.v1n2p109

URL: http://dx.doi.org/10.5430/crcp.v1n2p109

\begin{abstract}
Russell body cervicitis was reported only twice in the literature. Herein, we reported the third case. A 35 years old female patient presented with contact bleeding. On clinical examination, the cervix showed a small polyp measuring $1 \mathrm{~cm} \times$ $0.5 \mathrm{~cm} \times 0.5 \mathrm{~cm}$ which was subsequently biopsied. Microscopic examination revealed papillary configuration of the surface epithelium with intense infiltration of the underlying stroma by plasma cells with eccentric nuclei and prominent eosinophilic intra-cytoplasmic globules (Russell bodies). The globules were PAS positive and the cells showed positive immunoreactivity for CD138. Increased awareness of the existence of this type of inflammation may result in future reporting of similar cases, which may help to clarify the pathogenesis and causative agent of this uncommon condition in the cervix.
\end{abstract}

\section{Key words}

Plasma cells, Russell body, Cervicitis, CD138

\section{I ntroduction}

Russell bodies, first reported by Russell in 1890, refer to the immunoglobulin-containing inclusions, made by abnormal secretion of plasma cells, characterized by the distended rough endoplasmic reticulum ${ }^{[1]}$. Such plasma cells are called “Mott cells" and can be seen in chronic inflammatory reactions with prolonged antigenic stimulation ${ }^{[2]}$, as in Hashimoto's thyroiditis, rheumatoid arthritis and ulcerative colitis ${ }^{[3]}$ in addition to neoplastic processes such as plasmacytoma and B-cell lymphomas ${ }^{[4]}$.

This unusual pattern of inflammation has been described in some mucosal sites. In 1998, Tazawa and Tsutsumi ${ }^{[5]}$ found them in the gastric mucosa in association with Helicobacter pylori (HP) infection and they called that case "Russell body gastritis”. Zerosi et al. $1999{ }^{[6]}$ found them in inflamed dental pulp. In, 2005, Rubio ${ }^{[7]}$ reported a case of Barrett's oesophagus with chronic inflammation, having predominantly Mott cells with Russell bodies and they called the case "Mott cell Barrett’s oesophagitis". Russell body cervicitis was reported only twice in the literature. Herein, we reported the third case of Russell body cervicitis. 


\section{Case report}

A 35 years old female patient presented with contact bleeding. On clinical examination, the cervix showed a small polyp measuring $1 \mathrm{~cm} \times 0.5 \mathrm{~cm} \times 0.5 \mathrm{~cm}$ which was subsequently biopsied and sent for histological examination. Microscopic examination revealed papillary configuration of the surface epithelium (see Figure A), with underlying stroma intensely infiltrated by plasma cells with eccentric nuclei and prominent eosinophilic intra-cytoplasmic globules (Russell bodies) demonstrated by arrows (see Figure B). Histochemically, the globules were PAS positive (see Figure C) demonstrated by arrows. Immunohistochemically, the cells showed positive reactivity for CD138 (plasma cell marker) (see Figure D). A diagnosis of Russell body cervicitis was made. The patient was well with no evidence of recurrent symptoms six months following the initial presentation.

Figure. photomicrographs of the cervical biopsy showing papillary configuration of the surface epithelium (A), with underlying stroma intensely infiltrated by plasma cells with eccentric nuclei and prominent eosinophilic intra-cytoplasmic globules (Russell bodies) demonstrated by arrows (B). Histochemically, the globules were PAS positive (C). Immunohistochemically, the cells showed positive reactivity for CD138 (plasma cell marker) (D).
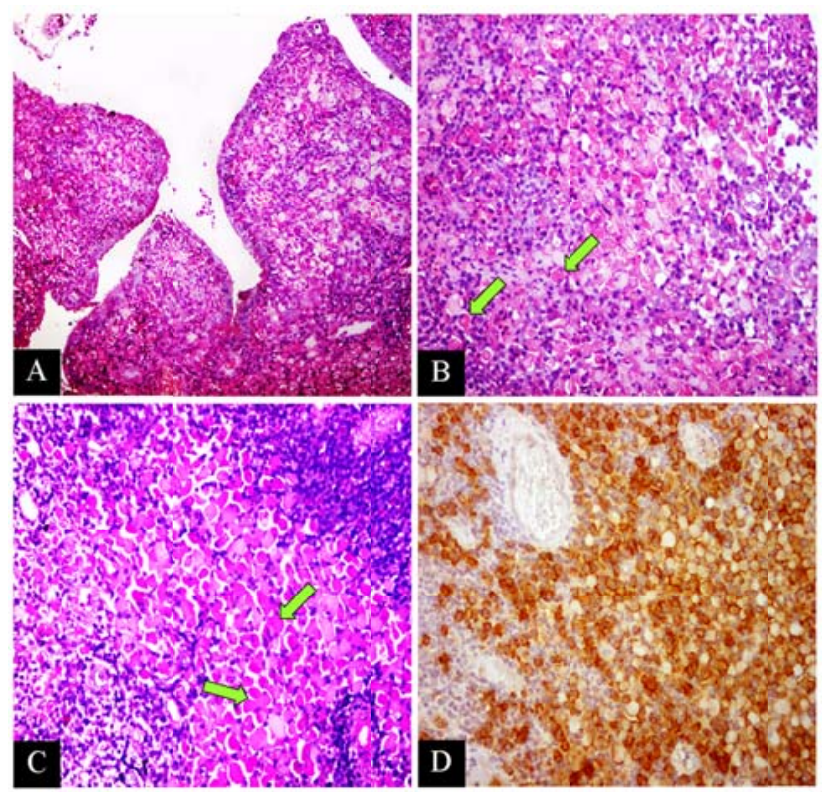

\section{Discussion}

Plasma cells with Russell bodies are not uncommon in inflammatory lesions with reactive plasma cells. Russell bodies have been described previously in the literature in cases of chronic gastritis ${ }^{[8]}$. This unusual pattern of inflammation has been described in the cervix. In 1890, Russell originally noted the hyaline acidophil bodies in the tissues adjacent to malignant tumors, and termed them the "characteristic organism of cancer" ${ }^{[9]}$. He also reported that "he could found them in malignant adenoma of the cervix!!” Moreover, Munsick and Janoveski in $1963^{[10]}$ could detect Russell bodies in about $50 \%$ of endocervical polyps and all were positive for PAS histochemical stain.

In 2006, Stewart and Leake ${ }^{[11]}$ reported the accumulation of plasma cells containing Russell bodies in the cervix and they called this case "Russell body cervicitis". Salmo and Farroha, $2007^{[12]}$ described the second case of Russell body cervicitis.

The presence of diffuse plasma cell infiltration with Russell body formation in Russell body gastritis is suggestive of an interaction between HP infection and gastric immune system ${ }^{[8]}$. Reviews of Russell body gastritis cases confirmed that many of the cases were infected by HP ${ }^{[13]}$. This agent causes damage to both superficial and crypt cells by cytokine production, such as interleukin-1, interleukin-6, inteleukin-8, and tumor necrosis factor causing chronic gastritis with diffuse plasma cell infiltration ${ }^{[2]}$. The over-stimulation of plasma cells by mucosal pathogens could lead to the accumulation of excess amounts of IgG in the cytoplasm ${ }^{[8]}$. 
Chronic cervicitis may be caused by a wide variety of organisms and can also have a non-infective aetiology but in most cases the histological changes are not specific ${ }^{[12]}$. Munsick and Janoveski in $1963^{[10]}$ explained the presence of Russell bodies in the cervix by the presence of active immunological process to an antigen which may be bacteria, contraceptive substance, ingredients of douche or constitute of seminal fluid. However, the reason for the accumulation of plasma cells as well as the life span of Mott cells is still unknown. Further studies are needed to clarify the pathogenesis and causative agent of this uncommon condition in the cervix.

The differential diagnosis of Russell body cervicitis includes plasmacytoma and malakplakia. The demonstration of light-chain restriction by immunohistochemestry technique helps in the differentiation between a reactive and a neoplastic plasma cell infiltrate. Malakoplakia is a rare chronic inflammatory disease that occurs most commonly in the genitourinary tract ${ }^{[14]}$. Definitive diagnosis of Malakoplakia is based on the histopathologic findings of the characteristic MichaelisGutmann bodies which are basophilic, PAS-positive structures with surrounding clear halos ${ }^{[15]}$.

In conclusion, we present the third case in the literature of "Russell body Cervicitis". Increased awareness of the existence of this type of inflammation may result in reporting more similar cases in the future, which will allow careful investigation of these cases in order to clarify the pathogenesis and causative agent of this uncommon condition in the cervix.

\section{Consent}

The authors have obtained a written, informed consent from the patient for publication of this case report.

\section{References}

[1] Hsu SM, Hsu PL, McMillan PN, Fanger H. Russell bodies: a light and electron microscopic immunoperoxidase study. Am J Clin Pathol. 1982; 77: 26-31. PMid: 6275697.

[2] Cambruzzi E, Pêgas KL, Laus FF. Russell body gastritis: case report. J Bras Patol Med Lab. 2012; 48(1): 41-44. http://dx.doi.org/10.1590/S1676-24442012000100008

[3] Wolkersdörfer GW, Haase M, Morgner A, Baretton G, Miehlke S. Monoclonal gammopathy of undetermined significance and Russell Body formation in Helicobacter pylori gastritis. Helicobacter. 2006; 11: 506-510. PMid: 16961813. http://dx.doi.org/10.1111/j.1523-5378.2006.00443.x

[4] Erbersdobler A, Petri S, Lock G. Russell body gastritis: an unusual, tumor-like lesion of the gastric mucosa. Arch Pathol Lab Med. 2004; 128: 915-7. PMid: 15270606.

[5] Tazawa K, Tsutsumi Y. Localized accumulation of Russell body-containing plasma cells in gastric mucosa with Helicobacter pylori infection: "Russell body gastritis”. Pathol Int. 1998; 48: 242-244. http://dx.doi.org/10.1111/j.1440-1827.1998.tb03901.x

[6] Zerosi C, Giardino L, Lafornara D, Scarola V. Presence of Russel bodies in chronic dental pulp inflammation. Minerva Stomatol. 1999 Jul-Aug; 48(7-8): 307-10. PMid: 10568106.

[7] C.A.RUBIO. Mott Cell (Russell Bodies) Barrett’s Oesophagitis. 2005; in vivo 19: 1097-1100.

[8] Ensari A, et al. An unusual presentation of Helicobacter pylori infection: so-called "Russell body gastritis". Virchows Arch. 2005; 446(4): 463-6. PMid: 15744498. http://dx.doi.org/10.1007/s00428-005-1215-5

[9] Welsh RA. Electron Microscopic Localization of Russell bodies in the Human Plasma Cell. Blood. 1960; 16: 1307-1312. PMid: 13843924.

[10] Munsick RA, Janoveski NA. Russell' bodies in endocervical poly. Obstetric and gynecology. 1963; 22(4).

[11] Stewart CJR, Leake R. Reactive plasmacytic infiltration with numerous Russell bodies involving the uterine cervix: "Russell body cervicitis”. Pathology. 2006; 38(2): 177-179. PMid: 16581662. http://dx.doi.org/10.1080/00313020600562003

[12] E Salmo, M Farroha. Russell Body Cervicitis: Report of A Case and Review of The Literature. The Internet Journal of Pathology. 2007; 7(1).

[13] Yoon JB, Lee TY, Lee JS, Yoon JM, Jang SW, Kim MJ, et al. Two Cases of Russell Body Gastritis Treated by Helicobacter pylori Eradication. Clin Endosc. 2012 Nov; 45(4): 412-6. http://dx.doi.org/10.5946/ce.2012.45.4.412

[14] Agnarsdottir M, Hahn L, Sellgren U, et al. Malacoplakia of the cervix uteri and vulva. Acta Obstet Gynecol Scand. 2004; 83: 214-6. PMid: 14756745. http://dx.doi.org/10.1080/j.0001-6349.2004.077c.x

[15] Velásquez López Juan G, Vélez Hoyos A, Uribe Arcila JF. Malakopla-sia in urology: six cases report and review of the literature. Actas Urol Esp. 2006; 30: 610-8. http://dx.doi.org/10.1016/S0210-4806(06)73502-1

Published by Sciedu Press 